Research

\title{
Characteristics of non-Hodgkin lymphoma patients in Otorhinolaryngology-HNS Department Zainoel Abidin General Hospital Banda Aceh
}

\author{
Fadhlia, Benny Kurnia, Lily Setiani, Yerni Karnita, Juniar, Iip Berliananda \\ Otorhinolaryngology Head and Neck Surgery Department \\ Medical Faculty of Syiah Kuala University /dr. Zainoel Abidin General Hospital, \\ Banda Aceh
}

\begin{abstract}
Background: Non-Hodgkin's lymphoma (NHL) is a primary malignancy in the lymphatic system and extranodal lymphoid tissue originating from B lymphocyte cells, T lymphocytes or natural killer (NK) cells. The incidence of NHL continues to increase with various characteristics. Objective: To find out the characteristics of NHL sufferers undergoing treatment in Otorhinolaryngology Head and Neck Surgery Department of dr. Zainoel Abidin Regional General Hospital (RSUDZA), Banda Aceh from January 2015 to December 2018. Method: This was an observational descriptive study conducted at Banda Aceh RSUDZA using retrospective secondary data collection from medical records that met the inclusion criteria, in total sampling method. Result: Found 32 research subjects, dominantly male (20), the highest age range was 56-65 years (10). The main complaints were neck lumps (10) and oropharynx lumps (11). The most common NHL was from B lymphocyte cells (6). The chemotherapy regimens used are cyclophosphamide, doxorubicin, vincristine, and prednisone (CHOP) and rituximab, cyclophosphamide, doxorubicin, vincristine, and prednisone (R-CHOP). The most frequent side effects are anemia, hypoalbuminemia, and leukopenia. Conclusion: The results showed that NHL was most common in men with an increased incidence in the fifth decade. Neck lumps are the most common complaint. The chemotherapy regimen used is CHOP and R-CHOP.
\end{abstract}

Keywords : Non-Hodgkin's Lymphoma, chemotherapy

\section{ABSTRAK}

Latar belakang: Limfoma Non-Hodgkin (LNH) adalah keganasan primer pada sistem limfatik dan jaringan limfoid ekstranodal yang berasal dari sel limfosit B, limfosit Tatau sel natural killer (NK). Kejadian LNH terus meningkat dengan berbagai karakteristik. Tujuan: Melihat karakteristik penderita LNH yang menjalani pengobatan di Departemen THT-KL RSUD dr. Zainoel Abidin (RSUDZA), Banda Aceh pada periode Januari 2015 sampai Desember 2018. Metode: Penelitian deskriptif observasional dengan pengambilan data sekunder secara retrospektif dari rekam medis yang memenuhi kriteria inklusi, dengan metode total sampling. Hasil: Didapatkan total subjek penelitian 32 orang, dominan pada lakilaki (20), rentang usia tertinggi antara 56-65 tahun (10). Keluhan utama terbanyak adalah benjolan di leher (10) dan benjolan orofaring (11). LNH yang berasal dari sel limfosit B paling banyak dijumpai (6). Regimen kemoterapi yang digunakan adalah cyclophosphamide, doxorubicin, vincristine, and prednisone $(C H O P)$ dan rituximab, cyclophosphamide, doxorubicin, vincristine, and prednisone (R-CHOP). Efek samping paling sering adalah anemia, hipoalbuminemia dan leukopenia. Kesimpulan: Hasil penelitian menunjukkan LNH paling sering pada laki-laki dengan angka kejadian meningkat pada dekade kelima. Keluhan yang paling sering adalah benjolan di leher. Regimen kemoterapi yang digunakan adalah CHOP dan $\mathrm{R}-\mathrm{CHOP}$.

Kata kunci: limfoma non-Hodgkin, kemoterapi 
Correspondence Address: Fadhlia. Otorhinolaryngology Head and Neck Surgery Department. Medical Faculty of Syiah Kuala University/dr. Zainoel Abidin General Hospital. Banda Aceh.

Email: yudiswife@gmail.com.

\section{INTRODUCTION}

Non-Hodgkin's lymphoma (NHL) is a large group of primary malignancies in the lymphatic system and extranodal lymphoid tissue that can originate from B lymphocytes, $\mathrm{T}$ lymphocytes, and natural killer (NK) cells. ${ }^{1}$ NHL is not limited to lymph nodes but can also involve extranodal organs. The Waldeyer's ring is one of the most frequently involved parts of the head and neck NHL. ${ }^{2}$ There are currently 36 disease entities categorized as NHL in the WHO classification. ${ }^{1}$ NHLs whose slow growth is called indolent/low grade and whose fast growth is called aggressive/high-grade. ${ }^{1}$ In 1997, NHL was reported as the leading cause of death from cancer in men aged 20-39 years. In 2000, in the United States, an estimated 54,900 new cases and 26,100 people died due to NHL. At present, the incidence of NHL in the United States is increasing with an increase of $5-10 \%$ per year. $^{3}$ The incidence of NHL increases with age and reaches a peak in the $80-84$ years age group. ${ }^{1,4}$ In Indonesia, the incidence of NHL is unsure. Some teaching centers/health services report various cases with varying incidents.

The exact cause of the malignancy of NHL in humans is unknown. However, there are several risk factors that cause NHL, namely oncogene, Epstein Barr virus infection, Human T-leukemia Virus-I (HTLV-I), autoimmune diseases and immune deficiency. ${ }^{5}$

The histological classification of NHL is a complex problem. The latest developments in a classification that are widely used and accepted by health centers are Working Formulation and REAL/WHO. ${ }^{1,5}$ The classification of Working Formulation is based on the aggressive nature of the disease and the response to therapy that divides NHL into three subtypes (low grade, intermediate grade, and high grade). ${ }^{1,4-6}$ Revised American European Lymphoma (REAL)/WHO classifies NHL based on immunophenotypic characteristics (B cells, $\mathrm{T}$ cells, and NK cells). This classification is expected to be the standard benchmark and way of consultation among medical hematology-oncologists. ${ }^{5}$

About two-thirds of patients with NHL usually experience persistent and painless superficial lymphadenopathy. Only about 20\% of NHL's patients have systemic symptoms. ${ }^{6,7}$ Over the past decade, considerable progress has been made for the NHL treatment approach. In general, the NHL is responsive to treatment, although the length of treatment response varies greatly. Treatment using a combination of chemotherapy can affect the prognosis of the disease. ${ }^{6}$

This study aims to look at the characteristics of non-Hodgkin's lymphoma patients in the Otorhinolaryngology Head and Neck Surgery Department of dr. Zainoel Abidin Hospital.

\section{METHOD}

This research is a descriptive study by taking secondary data from medical records. The study was conducted in the Otorhinolaryngology Head and Neck Surgery Department of dr. Zainoel Abidin Regional General Hospital, Banda Aceh for 4 years, starting from the period January 2015 to December 2018. The technique was total sampling where all patients who seek treatment in the Otorhinolaryngology HNS clinic and had been diagnosed as non-Hodgkin's lymphoma based on the examination of 
Ear Nose Throat (ENT) specialists, and anatomical pathology laboratory results both cytology and histopathology, and undergoing chemotherapy.

Data were tabulated and the percentage of each dependent and the independent variable was calculated so that the characteristics of non-Hodgkin's lymphoma patients were found in the form of demographic features, clinical symptoms, anatomic pathology results, cancer stages, chemotherapy regimens used, and post-chemotherapy blood laboratories. This study was approved by the Research Ethics Commission of the dr. Zainoel Abidin Regional General Hospital, Banda Aceh.

\section{RESULT}

The result obtained were 32 subjects who experienced NHL with a more dominant incidence rate in male, 20 subjects compared to 12 female, the most age range was 56-65 years as many as 10 subjects and $>65$ years as many as 8 subjects, with the most symptoms complained of were neck lumps, lumps on the nose, weakness, headaches and recurrent fever.

From the 11 patients who underwent immunohistochemical (IHC) examination, it was found that type B cell lymphoma was the most frequent type of NHL, found in 6 subjects. Of the 32 subjects studied, 2 subjects were not eligible for staging. Of the 30 subjects, stage I were 4 subjects, stage II were 6 subjects, stage III were 18 subjects, stage IV were 2 subjects. The most widely used chemotherapy regimens are the CHOP (cyclophosphamide, doxorubicin, vincristine, and prednisone) regimen used on 18 subjects and the R-CHOP (rituximab, cyclophosphamide, doxorubicin, vincristine, and prednisone) regimen used on 11 subjects. The most common side effects of chemotherapy are anemia, hypoalbuminemia, leukopenia, thrombocytopenia, electrolyte disorders, increased level of kidney and liver function.

Table 1. Characteristics of non-Hodgkin lymphoma patients in Otorhinolaryngology HNS Department dr. Zainoel Abidin Regional General Hospital Banda Aceh

\begin{tabular}{ccc}
\hline Characteristics & $\mathbf{N}$ \\
Male & 20 \\
Female & 12 \\
$56-65$ years old & 10 \\
$>65$ years old & 8 \\
Neck lumps & 18 \\
Oropharyngeal lumps & 11 \\
B cells Lymphoma Type & 6 \\
T cells and NK cells type & 1 \\
Stadium II & 6 \\
Stadium III & 18 \\
CHOP & 18 \\
R-CHOP & 11 \\
Anemia & 30 \\
Hypoalbuminemia & 29 \\
Leukopenia & 18
\end{tabular}




\section{DISCUSSION}

The result showed the incidence of NHL was more dominant in male than female with the most age was $56-65$ years and $>65$ years. NHL reportedly increases with age. NHL is more common at over 65 years old people. Several studies found the average age of patients with NHL was 58 years old, ranging from 14-89 years old. With a male-female ratio of $1.5: 1 .^{2}$ Symptoms that arise can be enlarged lymph nodes and accompanied by malaise, weight loss by $10 \%$ within 6 months, high fever $38^{\circ} \mathrm{C} 1$ week for no reason, night sweats, complaints of anemia. In addition to neck lumps, lumps can also arise in the nasal cavity, paranasal sinuses, and Waldeyer's ring. ${ }^{3,6-8}$

According to Laurini et al. ${ }^{9}$ the most frequent type of NHL was B-cell lymphoma type (87.3\%) and T-cell lymphoma (12.7\%). Among the B-cell lymphoma, diffuse large B-cell lymphoma (DLBCL) was the most common subtype $(40.0 \%)$. In addition to DLBCL, follicular lymphoma is another subtype that is most commonly found (34\%). According to Perry et al. ${ }^{10}$ DLBCL type is the most common $(42.5 \%)$ compared to other subtypes such as follicular lymphoma (15.3\%), marginal zone lymphoma (MZL) of mucosa associated lymphoid tissue (MALT) type (7\%), chronic lymphocytic leukemia/ small lymphocytic lymphoma (CLL/SLL; $11.3 \%$ ), mantle cell lymphoma (MCL; $5.9 \%$ ), precursor B-lymphoblastic leukemia/ lymphoma (2.4\%) and Burkitt-like lymphoma $(8.2 \%)$.

Other studies also stated DLBCL, follicular lymphoma (FL) and mantle cell lymphoma (MCL) were the main subtypes of B cell lymphoma. DLBCL had a shorter overall survival rate compared to other types and subtypes. ${ }^{11}$

In this study, the most common stages found were stage II and III, and the most widely used regimens were CHOP and
R-CHOP. Research conducted by Jeong et al. ${ }^{12}$ found stage I $(57.6 \%)$ more than stage II (42.4\%). Another study by Devi et al. ${ }^{13}$ the most common stage was stage II $(36 \%)$, followed by stage IV (27\%), stage III (25\%), and stage I (12\%). In contrast, the study of Lee et al. ${ }^{2}$ found that about $64.9 \%$ of patients had disease in stage I and II. Reksodiputro et al. ${ }^{5}$ stated that the CHOP protocol is the standard protocol for aggressive initial NHL therapy. Patients treated with the CHOP regimen, around 50\%-71\% achieved complete remission and $75 \%$ of them survived more than 3 years. Research conducted by Van Oers et al. ${ }^{14}$ stated that the addition of rituximab to the chemotherapy-induced CHOP regimen (RCHOP) resulted in an increase in complete response rates of $85.1 \%$, while which treated with the CHOP regimen the result was $72.3 \%$. Maintenance treatment with rituximab results in a very significant increase in progressionfree survival (PFS) rates either in patients who have partial remission after induction treatment or in those who have experienced complete remission. Research by Jeong et al. ${ }^{12}$ used CHOP (53.8\%) and R-CHOP $(46.2 \%)$ with a complete response rate of $72.1 \%$ treated with $\mathrm{CHOP}$ and $89.1 \%$ after R-CHOP therapy. Fridrik et al. ${ }^{15}$ study compared the use of R-CHOP and rituximab, cyclophosphamide, non-pegylated liposomal doxorubicin, vincristine and prednisolone (R-COMP) in DLBCL with the result that the overall response rate of the R-COMP group was $97.5 \%$ with complete remission $75 \%$. While the overall response rate with R-CHOP is $82 \%$ with complete remission $69.7 \%$. Many studies have shown that the combination therapy of CHOP and radiotherapy (RT) gives better results than chemotherapy alone in patients with limited stage DLBCL. ${ }^{12}$

Patients undergoing R-CHOP therapy, $75 \%$ of patients had a complete remission compared to those treated with the CHOP regimen of $63 \% .{ }^{16}$ Other studies also say that the combination of chemotherapy and radiotherapy in the early stages gives 
better results than chemotherapy alone, especially in the treatment of aggressive intermediate/high-grade NHL. ${ }^{5}$ The study of Ahlmann $\mathrm{M}^{17}$ found the side effects of cyclophosphamide administration were leukopenia, thrombocytopenia, anemia, nephrotoxic, cardiotoxic and hepatotoxic. These side effects depend on the number of doses given. Cyclophosphamide could also cause immunosuppression by decreasing the number of leukocytes. Side effects that could occur due to the use of rituximab were neutropenia, thrombocytopenia, headaches, stomach aches, and arrhythmias. Patients were also had high risk of developing bacterial and viral infections when receiving rituximab due to the decreased amount of B cells. Research conducted by Younes et al. ${ }^{18}$ found that out of 33 patients who received $\mathrm{R}-\mathrm{CHOP}$ regimen, all patients had one or more side effects, among others were neutropenia (73\%), thrombocytopenia (21\%), and anemia (18\%). In addition, other side effects could also be found such as febrile neutropenia (18\%), hypotension ( $6 \%$ ) and infections (23\%). Other studies also found that about $10 \%$ of patients undergoing treatment with doxorubicin could get heart complications up to 10 years after the cessation of chemotherapy. Men were more susceptible to this cardiotoxic effect, in particular to those aged $>65$ years old. ${ }^{19}$

This study showed that NHL was most common in men with an increased incidence in the fifth decade. Neck lumps were the most common complaint. The chemotherapy regimen used was $\mathrm{CHOP}$ and $\mathrm{R}-\mathrm{CHOP}$.

\section{REFERENCE}

1. Panduan Nasional Penanganan Kanker Limfoma Non-Hodgkin. Komite Nasional Penanggulangan Kanker. Kementerian Kesehatan Republik Indonesia. 2015:1-6.

2. Lee SJ, Suh CW, Lee SI, Kim WS, Lee WS, Kim HJ, et al. Clinical characteristics, pathological distribution, and prognostic factors in non-Hodgkin lymphoma of Waldeyer's ring: nationwide Korean study. Korean J Intern Med. 2014;29: 352-60.

3. Mengo SK, Surarso B. Pathogenesis Limfoma Non-Hodgkin Ekstra Nodal Kepala dan Leher. Dep/SMF Ilmu Kesehatan Telinga Hidung Tenggorok Bedah Kepala dan Leher Fakultas Kedokteran Universitas Airlangga / RSUD Dr. Soetomo Surabaya. Jurnal THTKL. 2009; 2 (1): 32-47.

4. National Institute for Health and Care Excellence (NICE). Guideline: methods, evidence, and recommendations. NonHodgkin's lymphoma: diagnosis and management. 2016; July:1-182.

5. Reksodiputro AH, Irawan C. Limfoma NonHodgkin. Dalam Buku Ajar Ilmu Penyakit Dalam. Setioyohadi B, Sudoyo AW, Alwi I, Simadibrata M, Setiati S, eds. Jilid II $4^{\text {th }}$ ed. Jakarta: Pusat Penerbitan Ilmu Penyakit Dalam, 2003. p. 717-23.

6. Fisher R, Oken MM. Clinical practice guidelines: non-Hodgkin's lymphomas. Cleve Clin J Med. 1995; 62 (S1): 1-42.

7. Casulo C, Rich L. Non-Hodgkin Lymphoma. Leukemia \& Lymphoma Society. 2013:1-51.

8. Sutrisno H, Dharmayuda TG, Rena RA. Gambaran Kualitas Hidup Pasien Kanker Limfoma Non Hodgkin yang Dirawat di RSUP Sanglah Denpasar. J Peny Dalam. 2010; 11 (2): 96-103.

9. Laurini JA, Perry AM, Boilesen E, Diebold J, MacLenna KA, Hermelink KM, et al. Classification of non-Hodgkin lymphoma in Central and South America: a review of 1028 cases. Blood. 2012; 120 (24): 4795-801.

10. Perry AM, Diebold J, Nathwani BN, MacLennan KA, Hermelink HKM, Bast $\mathrm{M}$, et al. Non-Hodgkin lymphoma in the developing world: review of 4539 cases from the International Non-Hodgkin Lymphoma Classification Project. Haematologica. 2016; 101(10): 1244-50.

11. Gao G, Liang X, Jiang J, Zhou X, Huang R, Chu Z, et al. Review Article: A systematic review and meta-analysis of immunochemotherapy with rituximab for B-cell nonHodgkin's lymphoma. Acta Oncol. 2010; 
49: $3-12$.

12. Jeong JK, Chung WK, Nam TK, Yang DH, Ahn SJ, Song JY, et al. Treatment results of radiotherapy following $\mathrm{CHOP}$ or $\mathrm{R}-\mathrm{CHOP}$ in limited-stage head-and-neck diffuse large B-cell lymphoma: a single institutional experience. Radiat Oncol J. 2017; 35(4): 317-24.

13. Devi AA, Sharma TD, Singh YI, Sonia H. Clinicopathological Profile of Patients with Non-Hodgkin's Lymphoma at a Regional Cancer Center in Northeast India. J Sci Soc. 2017; 44: 140-4.

14. Van Oers MHJ, Glabbeke MV, Giurgea L, Klasa R, Marcus RE, Kimby MW, et al. Rituximab Maintenance Treatment of Relapsed/Resistant Follicular NonHodgkin's Lymphoma: Long-Term Outcome of the EORTC 20981 Phase III Randomized Intergroup Study. J Clin Oncol 2010; 28: 2853-8.

15. Fridrik MA, Jaeger U, Petzer A, Willenbacher W, Keil F, Lang A, et al. Cardiotoxicity with rituximab, cyclophosphamide, nonpegylated liposomal doxorubicin, vincristine and prednisolone compared to rituximab, cyclophosphamide, doxorubicin, vincristine, and prednisolone in frontline treatment of patients with diffuse large B-cell lymphoma. A randomised phase-III study from the Austrian Cancer Drug Therapy Working Group [Arbeitsgemeinschaft Medikamentose Tumor Therapie AGMT] (NHL-14). Eur J Cancer. 2016; 58: 112-21.

16. Griffin MM, Morley N. Rituximab in the treatment of non-hodgkin's lymphoma - a critical evaluation of randomized controlled trial. Expert Opin. Biol. Ther. 2013; 13(5):803-11.

17. Ahlmann M, Hempel G. Review Article: The effect of cyclophosphamide on the immune system: implications for clinical cancertherapy. Cancer Chemother Pharmacol. 2016 (78): 661-71.

18. Younes A, Thieblemont C, Morschhauser F, Flinn I, Friedberg JW, Amorim S, et al. A combination of ibrutinib with rituximab, cyclophosphamide, doxorubicin, vincristine, and prednisone (R-CHOP) for treatmentnaive patients with $\mathrm{CD} 20$-positive $\mathrm{B}$-cell non-Hodgkin lymphoma: a non-randomized, phase 1b study. Lancet Oncol. 2014; 15: 1019-26.
19. Oktavia Y, Tocchetti CG, Gabrielson KL, Janssens S, Crijns HJ, Moens AL. Review article: Doxorubicin-induced cardiomyopathy: From molecular mechanisms to therapeutic strategies. J. Mol. Cell. Cardiol. 2012 (52): 1213-25. 